\title{
Peran Pejabat Pembuat Akta Tanah dalam Proses Peralihan Jual Beli Hak atas Tanah
}

\author{
Christiana Sri Murni* \\ Universitas Flores, Ende, Indonesia
}

\begin{abstract}
The Land Deed Official (PPAT) is a public official granted the authority to make deeds of transfer of land rights, assignment of land rights, and authorization to impose mortgage rights according to the prevailing laws and regulations. However, the question arises about how significant the role of PPAT is in transferring the sale and purchase of land rights, considering the laws and regulations governing land sale and purchase are potentially irrelevant to the current situation. This study aims to analyze the role of PPAT in transferring the sale and purchase of land rights. This type of research is normative juridical research; by using a statutory approach and a conceptual approach. This study uses primary and secondary legal materials. Then, it is described and analyzed to answer the problem to clarify the role of PPAT. The study's results reveal that the process of transferring land rights can be carried out using customary law with three options, namely adol plas, adol gadai, and adol tahunan. Then, from the national law's perspective, land rights commerce must meet the material requirements and formal requirements. PPAT has an essential role in registering land data, namely by making evidence of legal actions regarding land plots. The PPAT position has a strategic role in making authentic deeds a requirement in transferring land rights due to sale and purchase.
\end{abstract}

KEYWORDS: PPAT, Deed of Sale and Purchase, Transfer of Rights.

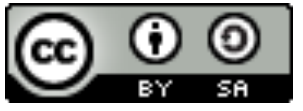

Copyright (C) 2021 by Author(s)

This work is licensed under a Creative Commons Attribution-ShareAlike 4.0 International License. All writings published in this journal are personal views of the authors and do not represent the views of this journal and the author's affiliated institutions.

HOW TO CITE:

Murni, Christiana Sri, "Peran Pejabat Pembuat Akta Tanah dalam Proses Peralihan Jual Beli Hak atas Tanah" (2021) 1:1 Jurnal Kajian Pembaruan Hukum 25-48. DOI: <https://doi.org/ 10.19184/jkph.v1i1.23384>

Submitted: 02/03/2021 Reviewed: 07/03/2021 Revised: 11/03/2021 Accepted: 16/03/2021

*Corresponding authors' e-mail: srimurni.uniflor61@gmail.com 


\section{PENDAHULUAN}

Tanah merupakan aset berharga dan berperan penting dalam kehidupan manusia. Hal ini karena manusia sangat tergantung kepada tanah untuk memenuhi kebutuhan hidupnya, khususnya untuk tempat tinggal. ${ }^{1}$ Dari segi ekonomi, tanah mempunyai nilai ekonomis yang tinggi; karena tanah mempunyai sifat tetap dan dapat dipergunakan pada masa depan. Dari waktu ke waktu, kebutuhan manusia akan tanah semakin meningkat; sejalan dengan pembangunan, pertumbuhan ekonomi, dan kepadatan penduduk. ${ }^{2}$ Terdapat peningkatan pula kebutuhan dukungan berupa jaminan kepastian hukum di bidang pertanahan.

Menurut penjelasan umum Peraturan Pemerintah Nomor 24 Tahun 1997 tentang Pendaftaran Tanah (PP No. 24/1997), pemberian jaminan kepastian hukum di bidang pertanahan, bagi seluruh rakyat Indonesia dapat terwujud melalui dua upaya. Pertama, memerlukan perangkat hukum yang tertulis, lengkap, dan jelas yang dilaksanakan dengan konsisten sesuai dengan jiwa dan isi ketentuan-ketentuannya; sehingga perlu membuat peraturan perundang-undangan yang diperintahkan Undang-Undang Nomor 5 Tahun 1960 tentang Peraturan Dasar Pokok-Pokok Agraria (UUPA) yang sesuai dengan jiwa dan asas UUPA tersebut. Kedua, untuk menghadapi kasus-kasus konkret di bidang pertanahan, pemberian jaminan kepastian hukum belum dapat diwujudkan hanya dengan tersedianya perangkat hukum yang memenuhi persyaratan. Akan tetapi, juga dibutuhkan penyelenggaraan pendaftaran tanah yang memungkinkan para pemegang hak atas tanah untuk dengan mudah membuktikan haknya atas tanah yang dikuasainya, dan memudahkan kegiatan perekonomian seperti jual beli, pembeli akan mudah mengetahui informasi yang dibutuhkan mengenai tanah yang akan dijadikan objek perbuatan hukum yang dilakukan. Oleh karena itu, keterangan tersebut tersimpan dalam kantor pertanahan sebagai pelaksana pendaftaran

1 Christiana Sri Murni, "Peralihan Hak atas Tanah Tanpa Sertifikat" (2018) 4:2 Lex Libr J Ilmu Huk 680-692 at 681.

2 Christiana Sri Murni, "Pendaftaran Peralihan Hak Milik atas Tanah Karena Pewarisan” (2020) 6:2 Lex Libr J Ilmu Huk 129-144 at 135. 
tanah dan terbuka untuk umum serta bagi pemerintah untuk melaksanakan kebijakan pertanahan. ${ }^{3}$

UUPA merupakan perangkat hukum pertanahan sebagai sendi dan landasan baik hukum nasional maupun kepastian hukum pada politik dan sistem pertanahan nasional. Secara tegas dinyatakan dalam Penjelasan UUPA bahwa Negara sebagai organisasi kekuasaan seluruh rakyat, bertindak selaku badan penguasa sehingga tepatlah jika bumi, air, dan kekayaan alam yang terkandung didalamnya pada tingkat tertinggi dikuasai oleh Negara. Pemerintah dapat memberikan hak-hak atas tanah yang dikuasainya kepada warga masyarakat sehubungan dengan hak menguasai oleh negara. Pemberian hak ini harus sesuai dengan peraturan perundang-undangan yang berlaku. Perbuatan hukum untuk pemberian hak ini dapat dilakukan antara lain dengan cara jual beli, hibah, dan lain-lain. Perbuatan hukum tersebut menimbulkan peralihan hak atas tanah dari pemilik tanah kepada pihak lain yang akan menerima hak atas tanah tersebut. ${ }^{4}$

Peralihan hak atas tanah harus di hadapan pejabat yang berwenang, sesuai Pasal 37(1) PP No. 24/1997 yang berbunyi:

"Peralihan hak atas tanah dan hak milik atas satuan rumah susun melalui jual beli, tukar-menukar, hibah, pemasukan dalam perusahaan dan perbuatan hukum pemindahan hak lainnya, kecuali pemindahan hak melalui lelang, hanya dapat didaftarkan jika dibuktikan dengan akta yang dibuat oleh PPAT yang berwenang menurut peraturan perundang-undangan yang berlaku.“

Menurut A.A. Andi Prajitno, ${ }^{5}$ Pejabat Pembuat Akta Tanah (PPAT) adalah pejabat yang ditunjuk dengan surat keputusan pemerintah dalam hal ini oleh Kepala Badan Pertanahan Nasional (BPN) untuk mewakili sebagian tugas

3 Yulia Amborowati, "Kekuatan Hukum Perjanjian Terhadap Perjanjian Pengikatan Jual Beli Hak atas Tanah dan Bangunan yang Belum Terdaftar” (2020) 18:1 Al Qodiri J Pendidikan, Sos Dan Keagamaan 302-319 at 311.

4 Mardansyah, "Analisis Prosedur Administrasi Peralihan Hak atas Tanah Hibah pada Kementerian Agraria dan Tata Ruang / Badan Pertanahan Nasional Kabupaten Bungo Provinsi Jambi” (2020) 5:1 Dialekt Publik J Adm Negara Univ Puter Batam 50-59 at 56.

5 AA Andi Prajitno, Pengetabuan Praktis Tentang Apa dan Siapa PPAT (Malang: Selaras, 2013) at 13. 
negara; yaitu membuat akta atau dokumen yang diperlukan oleh negara berkaitan dengan penertiban pelaksanaan peraturan pertanahan dan pendaftaran asset (kekayaan) negara berupa tanah dalam melayani kebutuhan masyarakat (public service) di bidang hukum keperdataan dengan objek tanah sebagaimana tercantum pada UUPA. Oleh karena itu, dapat disimpulkan bahwa PPAT mempunyai peran penting dalam kewenangannya membuat alat bukti tentang perbuatan hukum tertentu mengenai pengalihan; pembebanan hak atas tanah yang dijadikan dasar pendaftaran hak atas tanah pada Direktorat Jenderal Agraria yang sekarang pada BPN Republik Indonesia. ${ }^{6}$

Peran PPAT adalah melaksanakan sebagian kegiatan pendaftaran tanah dengan membuat akta tanah sebagai bukti telah dilakukannya perbuatan hukum tertentu mengenai hak atas tanah atau hak milik atas satuan rumah susun, yang akan dijadikan dasar bagi pendaftaran perubahan data pendaftaran tanah, seperti yang dinyatakan dalam Pasal 2(1) Peraturan Pemerintah Nomor 37 Tahun 1998 tentang Peraturan Jabatan Pembuat Akta Tanah (PP No. 37/1998). Perbuatan hukum tersebut menurut Pasal 2(1) PP No. 37/1998 meliputi: jual beli, tukar-menukar, hibah, pemasukan dalam perusahaan, pembagian hak bersama, pemberian hak guna bangunan/hak pakai atas tanah hak milik, pemberian hak tanggungan, dan pemberian kuasa membebankan hak tanggungan.

Akta itu sendiri ada yang berupa akta otentik dan akta di bawah tangan. ${ }^{7}$ Akta otentik adalah suatu akta yang di dalam bentuk yang ditentukan oleh Undang-Undang, dibuat oleh atau dihadapan pegawai-pegawai umum yang berkuasa untuk itu; di tempat dimana akta itu dibuatnya. Hal ini berdasarkan pada ketentuan Pasal 1868 Kitab Undang-Undang Hukum Perdata (KUHPer). Sedangkan mengenai akta di bawah tangan adalah tulisan yang

6 Dwina Natania, Lastuti Abubakar \& Nanda A Lubis, "Penyampaian Akta Pemberian Hak Tanggungan oleh Pejabat Pembuat Akta Tanah setelah Diberlakukannya Peraturan Menteri ATR/KPBN Nomor 5 Tahun 2020 Tentang Pelayanan Hak Tanggungan Terintegrasi Secara Elektronik" (2020) 3:2 Acta Diurnal J Ilmu Huk Kenotaraiatan 273-291 at 287.

7 Abdul Muthallib, "Pengaruh Sertifikat Hak atas Tanah sebagai Alat Bukti dalam Mencapai Kepastian Hukum” (2020) 12:1 Jurisprudensi J Ilmu Syariah, Perundangundangan, dan Ekon Islam 21-43 at 39. 
ditandatangani tanpa perantara pejabat umum. Akta otentik merupakan bukti yang paling akurat dan bernilai tinggi serta berperan penting dalam setiap hubungan hukum dalam kehidupan masyarakat, dalam berbagai hubungan bisnis, kegiatan perbankan, pertanahan, kegiatan sosial, dan lainlainnya. ${ }^{8}$ Kebutuhan akan bukti tertulis berupa akta otentik semakin meningkat sejalan dengan berkembangnya tuntutan masyarakat akan kepastian hukum dalam berbagai hubungan ekonomi dan sosial.

Melalui akta otentik inilah dapat ditentukan secara jelas hak dan kewajiban, menjamin kepastian hukum, dan sekaligus diharapkan dapat dihindari terjadinya sengketa. ${ }^{9}$ Sengketa dapat timbul akibat adanya ketidaksesuaian kepentingan para pihak, sehingga dengan adanya akta otentik ini diharapkan dapat dipakai sebagai bukti tertulis yang paling akurat dalam menyelesaikan sengketa. Sedangkan jika sebuah perbuatan hukum hanya dilakukan dengan akta di bawah tangan, maka akta tersebut tidak mempunyai kekuatan hukum yang pasti, karena akta tersebut hanya dibuat oleh pihak yang memberi dan pihak yang menerima dan ditandatangani oleh kedua belah pihak tersebut tanpa adanya kaitan dengan pejabat umum yang dapat membuktikan kebenaran dari akta tersebut. Hal di atas juga tidak dapat ditentukan dengan jelas hak dan kewajiban kedua belah pihak yang menandatangani akta tersebut, tidak dijanjikan tidak akan menimbulkan sengketa karena akta tersebut hanya diketahui oleh kedua belah pihak yang berkepentingan, sedangkan pihak ketiga yang mungkin mempunyai kepentingan atas objek perjanjian tersebut tidak mengetahui perbuatan hukum yang telah terjadi, sehingga dapat menimbulkan sengketa.

Akta yang dibuat oleh PPAT berlaku sebagai akta otentik, salah satu diantaranya adalah akta jual beli (AJB) yaitu akta yang dibuat bila seseorang ingin menjual tanah miliknya kepada orang lain. AJB berfungsi untuk mengurus surat-surat peralihan dari pemilik lama ke pemilik baru. Sebelum membuat AJB, PPAT melakukan pemeriksaan mengenai keaslian sertifikat

8 Ayu Larasati \& Raffles Raffles, "Peralihan Hak atas Tanah dengan Perjanjian Jual Beli Menurut Hukum Pertanahan Indonesia” (2020) 1:1 Zaaken J Civ Bus Law 127-144 at 143.

9 Irfan Iryadi, "Kedudukan Akta Otentik dalam Hubungannya dengan Hak Konstitusional Warga Negara” (2019) 15:4 J Konstitusi 796. 
ke kantor pertanahan. Pembuatan AJB dihadiri oleh penjual, calon pembeli, serta minimal dua orang saksi. ${ }^{10}$ AJB dibuat jika transaksi jual beli telah lunas pembayarannya. Menurut Keputusan Menteri Negara Perumahan Rakyat Nomor 9 Tahun 1995 tentang Pedoman Pengikatan Jual Beli Rumah; AJB harus ditandatangani oleh pembeli dan penjual di hadapan PPAT jika pembeli telah lunas membayar seluruh harga tanah beserta pajak dan biayabiaya lainnya yang terkait dengan transaksi jual beli.

Pembuatan AJB tersebut harus dilakukan sesuai dengan kejadian, status, dan data yang benar serta sesuai dengan hukum dan peraturan perundangundangan dan didukung oleh dokumen yang diharuskan ada dan menurut penelitian PPAT yang bersangkutan adalah benar. Bentuk baku dari akta PPAT sudah ditentukan oleh BPN yang berbentuk blanko akta; berbeda dengan akta notaris yang dibuat sendiri oleh notaris tergantung dari kebutuhan akan akta dan perbuatan hukum yang akan dilakukan oleh kliennya. Dapat tidaknya akta PPAT tersebut diproses oleh kantor pertanahan tergantung dari akta yang diberikan dengan dokumen-dokumen pendukungnya. ${ }^{11} \mathrm{Hal}$ ini disebabkan karena akta PPAT tersebut akan dipergunakan sebagai bukti otentik mengenai perbuatan hukum yang mengakibatkan adanya perubahan data yuridis pendaftaran tanah.

Kegiatan PPAT dalam pendaftaran tanah adalah pembuatan akta-akta tanah tertentu sebagaimana yang disebut dalam peraturan perundang-undangan tentang pendaftaran tanah. Akta tersebut berfungsi sebagai sumber data yang diperlukan dalam rangka memelihara data yang disimpan di kantor pertanahan sehingga data yang ada pada kantor pertanahan adalah data terbaru. Pada kenyataannya, masih banyak masyarakat yang belum memahami betul tentang arti peran PPAT dalam pembuatan AJB tanah. Masih banyak masyarakat yang melakukan jual beli tanah melalui akta di bawah tangan. Walaupun pembuatan akta di bawah tangan hanya dapat

10 Imam Surya Saputra, Ilyas Ismail \& Darmawan Darmawan, "Akibat Hukum Terhadap Akta Jual Beli yang Cacat Hukum” (2020) 8:2 J IUS Kaji Huk dan Keadilan 283.

11 Made Emy Andayani Citra \& I Made Sudirga, "Eksistensi Program Pendaftaran Tanah Sistematis Lengkap (Ptsl) dalam Mencegah Terbitnya Sertipikat Ganda Di Kantor Pertanahan Kota Denpasar" (2020) 2:1 J Huk Sar 1-15 at 13. 
dilakukan untuk tanah yang belum pernah didaftarkan di BPN, tetapi tetap dapat menimbulkan sengketa di kemudian hari.

Seringkali terjadi munculnya dua pihak yang mengaku sebagai pemilik atas tanah yang telah didaftarkan tersebut. Hal ini disebabkan karena masyarakat tidak mengetahui peran PPAT dalam kaitannya peralihan hak atas tanah karena jual beli. Di sisi lain, peraturan perundang-undangan yang mengatur jual beli tanah berpotensi tidak relevan dengan situasi saat ini; ${ }^{12}$ sehingga membuat peran PPAT dalam proses pengalihan jual beli hak atas tanah masih diperdebatkan, khususnya mengenai seberapa besar peran PPAT tersebut. Untuk itu, tulisan ini akan membahas tentang peran PPAT dalam proses peralihan hak atas tanah karena jual beli.

\section{METODE}

Jenis penelitian yang digunakan dalam penelitian ini adalah penelitian hukum normatif. Soerjono Soekanto dan Sri Mamudji menyatakan bahwa penelitian hukum normatif berkaitan dengan bahan pustaka merupakan data dasar yang dalam penelitian digolongkan sebagai data sekunder, yaitu buku, jurnal, dokumen resmi yang dikeluarkan pemerintah, asas-asas hukum, sistematika hukum, taraf sinkronisasi vertikal dan horisontal, perbandingan hukum, dan sejarah hukum. ${ }^{13}$ Pendekatan yang digunakan dalam penelitian ini adalah pendekatan perundang-undangan dan konseptual. Bahan hukum yang digunakan adalah bahan hukum primer dan bahan hukum sekunder. Setelah seluruh bahan hukum terkumpul; bahan hukum diolah dan dianalisis dengan menghubungkan bahan-bahan hukum yang satu dengan yang lain, kemudian dideskripsikan dan dianalisis untuk menjawab permasalahan yang kemudian diharapkan memperoleh kejelasan mengenai peran PPAT dalam proses peralihan jual beli hak atas tanah.

12 Ita Surayya, "Idiologi Hukum Pendaftaran Tanah dalam Sistem Hukum Agraria" (2020) 34:1 Jatiswara

13 Soerjono Soekanto \& Sri Mamudji, Penelitian Normatif Suatu Tinjauan Singkat (Jakarta: PT Raja Grafindo Persada, 2013). 


\section{JUAL BELI HAK ATAS TANAH MENURUT HUKUM ADAT}

Peralihan hak atas tanah yang berbentuk beralih maupun dialihkan, yaitu jual beli tanah merupakan perbuatan hukum berupa penyerahan hak atas tanah untuk selama-lamanya oleh pemilik tanah atau pemegang hak atas tanah sebagai penjual ke pihak lain sebagai pembeli, dan secara bersamaan pihak pembeli menyerahkan sejumlah uang sebagai harga, yang besarnya sesuai dengan kesepakatan kedua belah pihak. Peralihan hak atas tanah juga terjadi pada ranah hukum adat; mengingat hukum adat adalah pancaran moral dari pembangunan hukum nasional. ${ }^{14}$ Perihal tersebut, dapat dikaitkan dengan keberadaan Pasal 5 UUPA; yang menyebutkan bahwa Hukum Tanah Nasional kita adalah hukum adat. ${ }^{15}$ Dengan demikian, kita menggunakan konsepsi, asas-asas, lembaga hukum, dan sistem hukum adat; sehingga pengertian jual beli tanah menurut Hukum Tanah Nasional adalah pengertian jual beli menurut Hukum Adat. Hukum adat yang dimaksud Pasal 5 UUPA tersebut adalah hukum adat yang telah yang telah dihilangkan sifat kedaerahannya dan diberi sifat nasional.

Pada pengertian hukum adat, jual beli tanah merupakan suatu perbuatan hukum, yang mana pihak penjual menyerahkan tanah yang dijualnya kepada pembeli untuk selama-lamanya; pada waktu pembeli membayar harga (walaupun baru sebagian) tanah tersebut kepada penjual. ${ }^{16}$ Sejak itu, hak atas tanah telah beralih dari penjual kepada pembeli. Dengan kata lain, bahwa sejak saat itu pembeli telah mendapat hak milik atas tanah tersebut. Jadi, jual beli menurut hukum adat tidak lain adalah suatu perbuatan pemindahan hak antara penjual kepada pembeli. Maka bisa dikatakan bahwa jual beli menurut hukum adat itu bersifat "tunai" (kontan) dan "nyata" (konkret). ${ }^{17}$ Sedangkan pengertian jual beli tanah menurut hukum barat sebagaimana diatur dalam

14 Fradhana Putra Disantara, "Konsep Pluralisme Hukum Khas Indonesia sebagai Strategi Menghadapi Era Modernisasi Hukum” (2021) 6:1 Al-Adalah J Huk dan Polit Islam $1-36$ at 27.

15 Surayya, supra note 12.

16 I Made Krishna Dharma Kusuma, Putu Gede Seputra \& Luh Putu Suryani, "Peralihan Hak atas Tanah Melalui Jual Beli Berdasarkan Hukum Adat" (2020) 1:2 J Interpret Huk 213-217 at 215.

17 I Made Suwitra, "Eksistensi Tanah Adat dan Masalahnya Terhadap Penguatan Desa Adat di Bali” (2020) 4:1 Wicaksana J Lingkung dan Pembang 31-44 at 34. 
Pasal 1457 KUHPer yang berbunyi, "Jual beli adalah suatu perjanjian, dengan mana pihak yang satu mengikatkan dirinya untuk menyerahkan suatu kebendaan, dan pihak yang lain untuk membayar harga yang telah dijanjikan."

Perihal tentang jual beli tanah dalam perspektif hukum adat, dikenal tiga macam proses penjualan tanah. ${ }^{18}$ Pertama, jual lepas atau adol plas. Pada adol plas, pemilik tanah menyerahkan tanahnya untuk selama-lamanya kepada pihak lain (pembeli) dengan pembayaran sejumlah uang yang besarnya ditentukan atas dasar kesepakatan antara pemlik tanah dengan pihak lain (pembeli). Kedua, jual gadai atau adol gadai. Pada adol gadai, pemilik tanah pertanian (pembeli gadai) menyerahkan tanahnya untuk digarap kepada pihak lain (pemegang gadai) sebagai uang gadai dan tanah dapat kembali kepada pemiliknya apabila pemilik tanah menebus uang gadai. Ketiga, jual tahunan atau adol tahunan. Pada adol tabunan, pemilik tanah pertanian menyerahkan tanah untuk digarap dalam beberapa kali masa panen kepada pihak lain (pembeli) dengan pembayaran sejumlah uang yang besarnya ditentukan atas dasar kesepakatan antara pemilik tanah dan pembeli. Setelah beberapa kali masa panen sesuai kesepakatan kedua belah pihak, tanah pertanian diserahkan kembali oleh pembeli kepada pemilik tanah.

Menurut Boedi Harsono, ${ }^{19}$ jual beli tanah adalah perbuatan hukum yang berupa penyerahan hak milik (penyerahan tanah untuk selama-lamanya) oleh penjual kepada pembeli; yang pada saat itu juga pembeli membayar harganya kepada penjual. Jual beli yang mengakibatkan beralihnya hak milik atas tanah dari penjual kepada pembeli itu masuk dalam hukum agraria atau hukum tanah. Sifat jual beli tanah berdasarkan konsep Hukum Adat menurut Effendi Perangin adalah 'tunai' dan 'terang'. ${ }^{20}$ 'Tunai' atau kontan artinya harga tanah yang dibayarkan itu seluruhnya, tetapi bisa juga sebagian. Akan tetapi, biarpun dibayar sebagian, menurut hukum dianggap telah

18 Urip Santoso, Pendaftaran dan Peraliban Hak atas Tanah (Jakarta: Prenada Media Group, 2009).

19 Boedi Harsono, Hukum Agraria Indonesia: Sejarah Pembentukan Undang-Undang Pokok Agraria, Isi dan Pelaksanaannya, jilid 1 : ed (Jakarta: Djambatan, 1999).

20 Effendi Perangin, Hukum Agraria Indonesia: Suatu Telaah dari Sudut Pandang Praktisi Hukum (Jakarta: Radjawali, 1989). 
dibayar penuh. Pembayaran harga dan penyerahan haknya dilakukan pada saat yang bersamaan. Pada saat itu, jual beli menurut hukum telah selesai. Sisa harga yang belum dibayar dianggap sebagai utang pembeli kepada bekas pemilik tanah (penjual). Hal ini berarti, jika kemudian pembeli tidak membayar sisa harganya, maka bekas pemilik tanah tidak dapat membatalkan jual beli tanah tersebut.

Penyelesaian pembayaran sisa harga tersebut dilakukan menurut hukum perjanjian utang piutang. Sedangkan 'terang' artinya jual beli tanah tersebut dilakukan dihadapan kepala desa (kepala adat) yang tidak hanya bertindak sebagai saksi; tetapi juga dalam kedudukannya sebagai pihak yang menanggung bahwa jual beli tanah tersebut tidak melanggar hukum yang berlaku. Jual beli tanah yang dilakukan dihadapan kepala desa (kepala adat) menjadi 'terang' dan bukan perbuatan hukum yang 'gelap'. Dengan demikian, pembeli mendapatkan pengakuan dari masyarakat yang bersangkutan sebagai pemilik tanah yang baru dan mendapatkan perlindungan hukum jika pada kemudian hari ada gugatan terhadapnya dari pihak yang menganggap jual beli tanah tersebut tidak sah.

Menurut Pasal 1458 KUHPer, jual beli dianggap telah terjadi antara kedua belah pihak, seketika setelah pihak-pihak bersangkutan mencapai sepakat tentang kebendaan tersebut dan harganya, meskipun kebendaan itu belum diserahkan, maupun harganya belum dibayar. Sedangkan menurut Pasal 1459 KUHPer, hak milik atas barang yang dijual tidaklah berpindah kepada si pembeli, selama penyerahannya belum dilakukan menurut Pasal 612, Pasal 613 dan Pasal 616 tentang kebendaan. ${ }^{21}$ Dengan demikian, dapat disimpulkan bahwa jual beli adalah suatu perjanjian manakala salah satu pihak mengikatkan dirinya untuk menyerahkan tanah dan pihak lainnya membayar harga-harga yang telah ditentukan. Pada saat kedua pihak itu telah mencapai kata sepakat, maka jual beli telah dianggap terjadi; walaupun tanah belum diserahkan atau harganya belum dibayar. Akan tetapi sekalipun

21 Norman Hamonangan \& Yusman Yusman, "Perbuatan Melawan Hukum Akibat Peralihan Hak Milik Tanah Ditinjau dari Pasal 1365 KUH Perdata dan Pasal 26 Undang-Undang Nomor 5 Tahun 1960 Tentang Peraturan Dasar Pokok-Pokok Agraria dan PP No. 24 Tahun 1997 Tentang Pendaftaran Tanah” (2020) 3:1 Rechtsregel J Ilmu Huk 77. 
jual beli itu telah dianggap terjadi, namun hak atas tanah itu belum berpindah kepada pembeli. ${ }^{22}$

\section{PROSES JUAL BELI HAK ATAS TANAH MENURUT UUPA}

Perihal pengelolaan di bidang pertanahan, BPN sebagai lembaga atau Instansi Pemerintah yang berwenang untuk melakukan hal-hal yang berkaitan dengan pengelolaan tanah tidak bekerja sendiri. ${ }^{23}$ Pada saat menjalankan tugas dan wewenangnya, BPN dibantu oleh PPAT khususnya dalam hal yang berkaitan dengan pendaftaran tanah. PPAT berperan sebagai mitra Instansi BPN yang diberi kewenangan untuk membuat akta- akta tanah tertentu sebagaimana yang dijelaskan dalam Pasal 1 angka 24 PP No. 24/1997.24 PPAT lahir sebagai jawaban atas kebutuhan masyarakat akan jaminan kepastian hukum. Konflik atau persengketaan tanah yang sering terjadi dalam masyarakat adalah bukti ketidakmampuan UUPA menjadi landasan hukum yang dapat mengatasi masalah itu sendiri; sehingga dianggap perlu untuk membuat Undang - Undang Pertanahan yang baru yang diharapkan mampu menjadi solusi bagi penyelesaian berbagai konflik pertanahan yang terjadi.

Lahirnya PP No. 37/1998 bukanlah sebagai pengganti dari UUPA; tetapi sebagai aturan pelaksana, sehingga apa yang menjadi tujuan dari UUPA dapat terealisasikan dengan baik. Hal ini didasarkan pada ketentuan Pasal 19 UUPA yang menginstruksikan kepada Pemerintah untuk menyelenggarakan pendaftaran tanah di seluruh wilayah Republik Indonesia yang akan diatur dengan Peraturan Pemerintah Nomor 10 Tahun 1961 yang kemudian diganti dengan PP No. 24/1997, dimana dalam melakukan pendaftaran tanah Kepala Kantor Pertanahan dibantu oleh PPAT.

22 Verlia Kristiani, "Hukum yang Berkeadilan Bagi Hak Ulayat Masyarakat Hukum Adat (Kajian Dan Implementasi)" (2020) 11:1 ADIL J Huk 143-163 at 150.

23 Jamiat Akadol, Tamrin Muchsin \& Sri Sudono Saliro, "Kegagalan Mediasi: Sengketa Pertanahan di Kementerian Agraria Tata Ruang/Badan Pertanahan Nasional Sambas" (2020) 4:2 J Wawasan Yuridika 175.

${ }^{24}$ Abdul Mukmin \& Andri Pranata, "Peran Kantor Pertanahan Kota Samarinda dalam Penyelesaian Sengketa dan Konflik Pertanahan” (2020) 12:2 Yuriska J Ilm Huk 148159 at 151. 
PPAT sebagai pejabat umum yang diberi kewenangan untuk membuat aktaakta tanah tertentu. ${ }^{25}$ Akta tanah yang dimaksud adalah akta autentik, dimana mengenai bentuk, isi, maupun cara pembuatannya telah ditentukan oleh Peraturan Menteri Negara Agraria Nomor 3 Tahun 1997 tentang Ketentuan Pelaksana PP No. 24/1997. Kemudian dalam perkembangannya kedudukan PPAT sebagai pejabat umum lebih dipertegas dalam peraturan perundang-undangan lainnya yang dapat diuraikan secara jelas.

Pertama, Undang-Undang Nomor 4 Tahun 1996 Tentang Hak Tanggungan Atas Tanah Beserta Benda-benda yang Berkaitan dengan Tanah (UU No. 4/1996) menegaskan siapa PPAT dan bagaimana kedudukan PPAT, sebagaimana ditentukan dalam Pasal 1 angka 4 UU No. 4/1996 yaitu: "PPAT adalah pejabat umum yang diberi wewenang untuk membuat akta pemindahan hak atas tanah, akta pembebanan hak atas tanah, dan akta pemberian kuasa membebankan hak tanggungan menurut peraturan perundang-undangan yang berlaku.” Kedua, Pasal 1 angka 5 Peraturan Pemerintah Nomor 40 Tahun 1996 Tentang Hak Guna Usaha, Hak Guna Bangunan dan Hak Pakai Atas Tanah menyebutkan bahwa "PPAT adalah Pejabat Umum yang diberi kewenangan untuk membuat akta-akta tanah.”

Tugas dan wewenang PPAT berdasarkan PP No. 24/1997 adalah membuat akta-akta tanah tertentu. PPAT bertugas melaksanakan sebagian kegiatan pendaftaran tanah dengan membuat akta sebagai bukti telah dilakukannya perbuatan hukum tertentu. ${ }^{26}$ Akta-akta tanah yang dimaksud adalah akta autentik sebagai bukti telah dilakukannya perbuatan hukum yang berkaitan dengan peralihan hak atas tanah. Perbuatan hukum yang dimaksud berdasarkan ketentuan Pasal 2 PP No. 37/1998 adalah: (1) Jual beli, (2) Tukar-menukar, (3) Hibah, (4) Pemasukan ke dalam perusahaan (inbreng), (5) Pembagian hak bersama, (6) Pemberian Hak Guna Bangunan / Hak

25 Shirley Zerlinda Anggraeni \& Marwanto Marwanto, "Kewenangan dan Tanggung Jawab Hukum Pejabat Pembuat Akta Tanah dalam Pelaksanaan Pendaftaran Hak Tanggungan Secara Elektronik" (2020) 5:2 Acta Com 261.

${ }^{26}$ Mahendra Wardhana et al, Registration of Electronic Integrated Mortgage Rights of the Written Certificate of Land Rights in the Name of the Debtor (Paris, France: Atlantis Press, 2020). 
Pakai Atas Tanah Hak Milik, (7) Pemberian Hak Tanggungan, dan (8) Pemberian kuasa membebankan Hak Tanggungan.

Akta yang dibuat PPAT merupakan akta autentik yang berfungsi sebagai bukti untuk memastikan dilakukannya suatu peristiwa hukum dengan tujuan untuk menghindari terjadinya sengketa. Oleh karena itu, akta PPAT harus dibuat sedemikian rupa agar tidak memuat hal-hal yang kurang jelas sehingga menimbulkan sengketa di kemudian hari. ${ }^{27}$ Berdasarkan ketentuan Pasal 4(1) PP No. 37/1998 menegaskan bahwa PPAT hanya berwenang membuat akta mengenai hak atas tanah atau hak milik atas satuan rumah susun yang terletak di wilayah kerjanya.

Pengecualian dari Pasal 4(1) ditentukan dalam Pasal 4 (2), yaitu untuk akta tukar-menukar, akta pemasukan dalam perusahaan (inbreng) dan akta pembagian hak bersama mengenai beberapa hak atas tanah dan hak milik atas satuan rumah susun yang tidak semuanya terletak di dalam daerah kerja seseorang PPAT, dapat dibuat oleh PPAT yang daerah kerjanya meliputi salah satu bidang tanah atau satuan rumah susun yang haknya menjadi objek perbuatan hukum. Sedangkan PPAT khusus hanya berwenang membuat akta mengenai perbuatan hukum yang disebut secara khusus dalam penunjukannya (Pasal 3 PP No. 37/1998).

Beberapa ahli hukum agraria yang berpendapat bahwa akta yang dibuat oleh PPAT adalah akta autentik; antara lain pendapat A. A Andi Prajitno yang menyatakan bahwa akta PPAT merupakan akta autentik yang berisikan tentang peralihan dan pembebanan hak atas tanah dan hak milik atas satuan rumah susun sebagai alat bukti tertulis yang langsung berhubungan dengan hukum pembuktian dan merupakan bagian dari hukum keperdataan. ${ }^{28}$ Menurut A.P. Parlindungan, ${ }^{29}$ PPAT adalah pejabat umum, konsekuensinya akta-akta yang dibuatnya adalah akta autentik. Makna dari akta autentik adalah jika terjadi suatu masalah atas akta PPAT tersebut; pengadilan tidak perlu memeriksa kebenaran isi dari akta tersebut, ataupun

27 Nurbaedah Nurbaedah, "Penyelesaian Sengketa Sumber Daya Agraria Pada Tanah Perkebunan Bekas Hak Guna Usaha” (2020) 6:2 Divers J Huk 220-233 at 222.

28 Prajitno, supra note 5.

29 AP Parlindungan, Komentar Atas Undang-Undang Pokok Agraria (Bandung: Madar Maju, 1991). 
tanggal ditandatanganinya. Demikian pula keabsahan dari tanda tangan dari pihak-pihak; asal saja tidak dapat dibuktikan adanya pemalsuan, penipuan, maupun lain-lain kemungkinan akta tanah tersebut dapat dinyatakan batal ataupun harus dinyatakan batal.

Menurut Irawan Soerodjo, ${ }^{30}$ hakekat akta PPAT sebagai akta autentik jika ditinjau dari Pasal 1868 Burgerlijk Wetboek (BW) adalah suatu akta dalam bentuk yang ditentukan oleh Undang-Undang, dibuat oleh atau dihadapan pejabat yang berwenang untuk itu ditempat dimana akta dibuatnya. Adapun yang dimaksud Undang-Undang dalam pasal tersebut adalah peraturan perundang-undangan. Hak atas tanah yang dapat dijadikan objek jual beli adalah Hak Milik, Hak Guna Usaha, Hak Guna Bangunan, Hak Pakai atas tanah negara dengan ijin dari pejabat yang berwenang, dan Hak Milik atas Satuan Rumah Susun sebagaimana diatur dalam Undang-Undang Nomor 16 Tahun 1985 tentang Rumah Susun.

Namun, tidak semua hak atas tanah dapat dijadikan objek jual beli. Hak atas tanah yang tidak dapat diperjualbelikan adalah hak pakai atas tanah negara yang diberikan untuk waktu yang tidak ditentukan selama tanahnya digunakan untuk keperluan tertentu. Misalnya, hak pakai yang dimiliki oleh lembaga/instansi Pemerintah, Perwakilan Negara Asing atau Badan/Organisasi Internasional, dan Badan Sosial (lihat penjelasan Pasal 45 Peraturan Pemerintah Nomor 40 Tahun 1996 tentang Hak Guna Usaha, Hak Guna Bangunan, dan Hak Pakai).

Peralihan hak atas tanah dalam bentuk jual beli harus memenuhi beberapa syarat yang telah ditentukan oleh peraturan perundang-undangan yang berlaku. ${ }^{31}$ Apabila syarat-syarat yang telah ditentukan tidak terpenuhi; maka akan membawa konsekuensi pada legalitas jual beli hak atas tanah tersebut. Di samping itu, apabila suatu perbuatan jual beli hak atas tanah tidak memenuhi syarat, juga dapat berkonsekuensi tidak dapat didaftarkannya peralihan hak atas tanah melalui jual beli tersebut. J. Andy Hartanto

30 Irawan Soerodjo, Kepastian Hukum Hak Atas Tanah di Indonesia (Surabaya: Arloks, 2003).

31 Mahendra Wardhana, Indri Fogar Susilowati \& Dita Perwitasari, Registration of Transfers of Land of Rights for Nominee in the Post of Tax Amnesty (Paris, France: Atlantis Press, 2018). 
memberikan dua syarat dalam proses jual beli hak atas tanah; yaitu syarat material dan syarat formil. ${ }^{32}$

Syarat materil jual beli hak atas tanah adalah tertuju pada subjek dan objek hak yang akan diperjual-belikan. Pemegang hak atas tanah harus mempunyai hak dan berwenang untuk menjual hak atas tanah. Di samping itu, pembeli juga harus memenuhi syarat sebagai pemegang (subjek) hak dari hak atas tanah yang menjadi objek jual beli. Terdapat beberapa syarat penjual, antara lain: (1) Penjual adalah orang yang namanya tercantum dalam sertifikat atau alat bukti lain selain sertifikat; (2) Penjual harus sudah dewasa menurut ketentuan peraturan perundang-undangan yang berlaku; (3) Apabila penjual masih belum dewasa atau masih berada di bawah umur (minderjarig) maka untuk melakukan jual beli harus diwakili oleh walinya; (4) Apabila penjual berada di dalam pengampuan (curatele), maka untuk melakukan transaksi jual beli harus diwakili oleh wali pengampu atau kuratornya; (5) Apabila penjual diwakili oleh orang lain sebagai penerima kuasa, maka penerima kuasa menunjukkan surat kuasa notaril atau surat kuasa otentik yang dibuat oleh pejabat yang berwenang; (6) Apabila hak atas tanah yang akan dijual merupakan harta bersama dalam perkawinan maka penjual harus mendapatkan persetujuan terlebih dahulu dari suami/istri yang dituangkan dalam akta jual beli.

Pembeli hak atas tanah-pun memiliki beberapa persyaratan, diantaranya: (a) Apabila objek jual beli tersebut merupakan tanah hak milik, subjek yang dapat membeli tanah adalah perseorangan warga negara Indonesia, bank pemerintah, badan keagamaan, dan badan sosial; (b) Apabila objek jual beli tersebut merupakan tanah Hak Guna Usaha, subjek yang dapat membeli tanah adalah perseorangan warga negara Indonesia, dan badan hukum yang didirikan menurut hukum Indonesia dan berkedudukan di Indonesia; (c) Apabila objek jual beli tanah tersebut merupakan tanah Hak Guna Bangunan, subjek yang dapat membeli tanah adalah perseorangan warga negara Indonesia, dan badan hukum yang didirikan menurut hukum Indonesia dan berkedudukan di Indonesia; (d) Apabila objek jual beli tanah

32 J Andy Hartanto, Hukum Pertanahan, Karakteristik Jual Beli Tanah yang Belum Terdaftar Hak Atas Tanahnya (Surabaya: LaksBang Justitia, 2014). 
tersebut adalah merupakan hak pakai, maka pihak yang dapat membeli tanah adalah subjek hak pakai yang bersifat privat; yaitu perseorangan warga negara asing yang berkedudukan di Indonesia, badan hukum yang didirikan menurut hukum Indonesia dan berkedudukan di Indonesia, dan badan hukum asing yang mempunyai perwakilan di Indonesia.

Syarat formil dalam jual beli hak atas tanah adalah meliputi formalitas transaksi jual beli tersebut. Formalitas tersebut meliputi akta yang menjadi bukti perjanjian jual beli serta pejabat yang berwenang membuat akta tersebut; oleh karena itu, dalam rangka pendaftaran pemindahan hak, maka syarat formil jual beli hak atas tanah harus dibuktikan dengan akta yang dibuat oleh dan dihadapan PPAT. Akta yang dibuat oleh PPAT tersebut merupakan atau dikualifikasikan sebagai akta otentik. ${ }^{33}$ Syarat formil dalam jual beli hak atas tanah tidak mutlak harus dibuktikan dengan akta PPAT, Kepala kantor pertanahan kabupaten/kota dapat mendaftar pemindahan haknya meskipun tidak dibuktikan dengan akta PPAT. Hal ini ditegaskan dalam Pasal 37(2) PP No. 24/1997 sebagai berikut:

"Dalam keadaan tertentu sebagaimana yang ditentukan oleh menteri, Kepala Kantor Pertanahan dapat mendaftarkan pemindahan hak atas bidang tanah hak milik, yang dilakukan di antara perorangan warga negara Indonesia yang dibuktikan dengan akta yang tidak dibuat oleh PPAT, tetapi yang menurut Kepala Kantor Pertanahan tersebut kadar kebenarannya dianggap cukup untuk mendaftar pemindahan hak yang bersangkutan."

Atas dasar ketentuan Pasal 37 PP No. 24/1997 menunjukan bahwa untuk kepentingan pemindahan hak kepada kantor pertanahan, jual beli hak atas tanah harus dibuktikan dengan akta PPAT. Namun dalam keadaan tertentu, kepala kantor pertanahan dapat mendaftar pemindahan hak atas tanah bidang tanah hak milik, jika para pihaknya (penjual dan pembeli) perseorangan warga negara Indonesia yang dibuktikan dengan akta yang tidak dibuat oleh PPAT, tetapi kebenarannya dianggap cukup untuk mendaftar pemindahan hak yang bersangkutan.

33 Purwaning Rahayu Sisworini, Abdul Majid \& Herman Suryokumoro, "Penerapan Honorarium PPAT sebagai Upaya untuk Penyetaraan Pelayanan (Studi Kasus Di Kota Malang)" (2020) 8:3 J IUS Kaji Huk dan Keadilan 512. 


\section{PERAN PPAT DALAM PERALIHAN HAK ATAS TANAH KARENA JUAL BELI}

Prosedur peralihan hak atas tanah karena jual beli melalui pembuatan akta jual beli oleh PPAT menurut Mariam, akta PPAT harus ditafsirkan bukan semata-mata sebagai alat bukti melakukan pendaftaran; akan tetapi juga sebagai syarat mutlak adanya perjanjian penyerahan. ${ }^{34} \mathrm{Hal}$ ini sesuai dengan Pasal 23(2) jo Pasal 19 Peraturan Pemerintah Nomor 10 Tahun 1961 tentang Pendaftaran Tanah. Pada hukum pertanahan, transaksi jual beli tanah dapat dilaksanakan oleh PPAT, Camat juga dapat ditunjuk sebagai PPAT sementara oleh Kepala Badan Pertanahan Nasional (BPN). Hal ini perlu mendapat perhatian secara serius dalam rangka melayani masyarakat; khususnya mengenai Akta Jual Beli (AJB) PPAT di daerah-daerah yang belum cukup terdapat PPAT.

Selain itu, oleh karena fungsinya di bidang pendaftaran tanah sangat penting bagi masyarakat yang memerlukan; maka fungsi tersebut harus dilaksanakan di seluruh wilayah negara Indonesia. Oleh karena itu, di wilayah yang belum cukup terdapat PPAT, camat perlu ditunjuk sebagai PPAT Sementara. Makna atas daerah yang belum cukup terdapat PPAT adalah daerah yang jumlah PPAT-nya belum memenuhi jumlah formasi yang ditetapkan Menteri/Kepala Badan Pertanahan Nasional sesuai dengan Pasal 14 PP No. 37/1998. Di daerah yang cukup terdapat PPAT dan merupakan daerah tertutup untuk pengangkatan PPAT baru, camat baru tidak dapat lagi ditunjuk sebagai PPAT Sementara. ${ }^{35}$

Teruntuk desa-desa dalam wilayah yang terpencil, Kepala BPN dapat menunjuk PPAT Sementara. Ketentuan ini dimaksudkan untuk memberikan pelayanan pada rakyat di daerah terpencil, yang tidak ada PPAT untuk melaksanakan perbuatan hukum peralihan hak atas tanah. Mereka yang ditunjuk sebagai PPAT Sementara adalah Pejabat Pemerintah

34 Adrian Sutedi, Peralihan Hak atas Tanah dan Pendaftarannya (Jakarta: Sinar Grafika, 2014).

35 Irfan Iryadi, "Kepastian Hukum Kedudukan Camat sebagai PPAT Sementara” (2020) 11:1 Negara Huk Membangun Huk untuk Keadilan dan Kesejaht 1-19 at 15. 
yang menguasai keadaan daerah yang bersangkutan, yaitu Kepala Desa (sesuai Penjelasan Pasal 7(2) PP No. 24/1997 tentang Pendaftaran Tanah). Penunjukan Kepala Desa sebagai PPAT Sementara dilakukan oleh Kepala BPN berdasarkan letak desa yang sangat terpencil dan banyaknya bidang tanah yang belum terdaftar di wilayah desa tersebut.

Sementara dapat dijelaskan bahwa PPAT khusus adalah pada jabatan induk instansi Pemerintah yang dipegangnya; yang jika pejabat yang bersangkutan dimutasikan atau diganti oleh orang lain sehingga tidak lagi menjabat Kepala Desa, Camat, Kepala Kantor Pendaftaran Tanah, maka secara otomatis tidak berwenang membuat akta PPAT sejak tanggal keputusan pemindahan atau penggantian pejabat yang bersangkutan. Hal ini sebagaimana diatur dalam Pasal 6(4) Peraturan Menteri Agraria/Kepala BPN Nomor 4 Tahun 1999 tentang Ketentuan Pelaksanaan PP No. 37/1998.

Menurut Harun A1-Rosyid, ${ }^{36}$ AJB tanah merupakan suatu hal yang sangat penting yang berfungsi untuk terjadinya pemindahan hak milik atas tanah dan terjadinya kepemilikan Tanah. Agar transaksi jual beli bisa dipertanggung-jawabkan; maka keberadaan saksi juga mutlak penting, oleh karena apabila salah satu dari pihak penjual dan pembeli ingkar dan menjadi sengketa, maka kedua saksi inilah yang akan menjelaskan kepada hakim bahwa mereka benar-benar telah melakukan jual beli tanah. Hal tersebut berlaku di daerah pedesaan yang camat atau kepala desanya belum ditunjuk sebagai PPAT Sementara; sedangkan banyak penduduk pedesaan yang melakukan jual beli tanah tanpa akta PPAT tetapi dilakukan dihadapan Kepala desa atau Camat. Perihal jual beli tanah dengan status hak milik adat, tanah yang belum bersertifikat mengharuskan adanya keterangan tertulis dari Lurah tentang kebenaran tanah yang diperjualbelikan di wilayahnya itu. Pemilik girik atau ketitir yang dikeluarkan sebelum tahun 1960 bisa mendapat sertifikat dengan cara konversi. Adapun girik dan ketitir yang dikeluarkan sesudah tahun 1960 harus melalui permohonan hak kepada sub Direktorat Agraria wilayah Kota.

${ }^{36}$ Harun Al-Rosyid, Sekilas tentang Jual Beli Tanah, 1st ed (Jakarta: Ghalia Indonesia, 1987). 


\section{PROSEDUR PEMBUATAN AJB DI KANTOR PPAT}

Setelah ada kesepakatan mengenai harga tanah antara penjual dan calon pembeli, selanjutnya penjual dan calon pembeli datang ke kantor PPAT yang wilayah kerjanya meliputi letak tanah yang akan dijual untuk membuat AJB. Hal-hal yang diperlukan dalam pembuatan AJB di Kantor PPAT -yang harus dibawa penjual asli-adalah sertifikat hak atas tanah yang akan dijual, Kartu Tanda Penduduk, bukti pembayaran Pajak Bumi dan Bangunan (PBB) sepuluh tahun terakhir, surat persetujuan suami istri serta Kartu Keluarga bagi yang telah berkeluarga. Syarat yang harus dibawa oleh calon pembeli yaitu Kartu Tanda Penduduk dan Kartu Keluarga.

Proses pembuatan AJB di Kantor PPAT meliputi persiapan pembuatan AJB sebelum dilakukan proses jual beli. Pada tahap ini, dilakukan pemeriksaan mengenai keaslian dari sertifikat di kantor pertanahan untuk mengetahui status sertifikat saat ini seperti keasliannya; apakah sedang dijaminkan kepada pihak lain atau sedang dalam sengketa kepemilikan dan terhadap keterangan sengketa atau tidak. Oleh karena itu, harus disertai surat pernyataan tidak sengketa atas tanah tersebut. Terkait status tanah dalam sengketa maka PPAT akan menolak pembuatan AJB atas tanah tersebut. ${ }^{37}$ Calon pembeli dapat membuat pernyataan bahwa dengan membeli tanah tersebut maka tidak lantas menjadi pemegang hak atas tanah yang melebihi ketentuan batas luas maksimum. Penjual diharuskan membayar Pajak Penghasilan (Pph) sedangkan pembeli diharuskan membayar Bea Perolehan Hak Atas Tanah dan anggunan (BPHTB) dengan ketentuan Pajak Penjual $(\mathrm{Pph})=\mathrm{NJOP} /$ harga jual $\times 5 \%$; Pajak Pembeli $(\mathrm{BPHTB})=(\mathrm{NJOP} /$ harga jual-nilai tidak kena pajak) x 5\%. Papos.

Pajak penghasilan dan Bea Perolehan Hak Atas Tanah dapat dibayarkan di bank atau kantor pos. Sebelum pajak penghasilan dan Bea Perolehan Hak Atas Tanah dilunasi, akta belum dapat ditandatangani. Pada pembuatan AJB harus dihadiri oleh penjual dan calon pembeli atau orang yang diberi kuasa dengan surat kuasa tertulis. Di sisi lain, dalam pembuatan akta harus

37 Della Monika, "Analisis Yuridis Eksistensi Pejabat Pembuat Akta Tanah (PPAT) dalam Perspektif Pendaftaran Tanah di Kecamatan Tanjungpinang Timur (Studi Penelitian Dikantor Notaris dan Pejabat Pembuat Akta Tanah Afika Hersany)" (2020) 7:1 J Selat 65-86 at 77. 
dihadiri oleh sekurang-kurangnya dua orang saksi. PPAT akan membacakan serta menjelaskan mengenai isi dan maksud pembuatan AJB, dan bila isi AJB disetujui maka oleh penjual dan calon pembeli; maka akta tersebut akan ditandatangani oleh para pihak, sekaligus saksi dan PPAT sendiri.

Notaris atau PPAT berkewajiban membacakan AJB di hadapan penghadap dengan dihadiri oleh paling sedikit dua orang saksi dan ditandatangani pada saat itu juga oleh penghadap, saksi, dan Notaris atau PPAT. Apabila syarat formal dalam pembuatan akta tidak dipenuhi, maka akta yang dibuat oleh Notaris atau PPAT hanya mempunyai kekuatan pembuktian sebagai akta di bawah tangan. Akta dibuat rangkap dua lembar asli, satu disimpan oleh PPAT di Kantor PPAT dan lembar lainnya akan disampaikan kepada kantor pertanahan setempat untuk keperluan balik nama atas tanah; sedangkan salinannya akan diberikan kepada masing-masing pihak. Setelah pembuatan AJB, pemohon mengajukan pendaftaran tanah objek jual beli kepada Kepala kantor pendaftaran tanah kabupaten/kota yang wilayah kerjanya meliputi letak tanah yang bersangkutan. Pada pendaftaran tanah ini, disertakan bukti identitas penerima hak atas tanah dalam jual beli yang masih berlaku oleh pemohon AJB yang dibuat oleh PPAT. ${ }^{38}$ Kepala kantor pertanahan kabupaten/kota yang wilayah kerjanya meliputi letak tanah yang bersangkutan melakukan perubahan nama pemegang hak atas tanah dari pemegang hak atas tanah yang lama menjadi atas nama pemegang hak atas tanah yang baru. Kepala kantor pertanahan Kabupaten/Kota yang wilayah kerjanya meliputi tanah yang bersangkutan menyerahkan sertifikat hak atas tanah kepada pemohon pendaftaran tanah.

\section{KESIMPULAN}

Prosedur peralihan hak atas tanah karena jual beli harus dibuktikan dengan akta otentik yang dibuat oleh PPAT. Berdasarkan PP Nomor 10 Tahun 1961 sebagaimana telah diperbaharui dengan PP No. 24/1997 tentang Pendaftaran Tanah, jual beli atas tanah dilakukan oleh para pihak di hadapan

38 Daniella Herera Yosifany Hutagalung, "Perlindungan Hukum Terhadap Notaris Dan Ppat Sebagai Pihak Pelapor Dalam Tindak Pidana Pencucian Uang” (2020) 34:1 Jatiswara. 
PPAT yang bertugas membuat AJB tanah. Jual beli tanah yang dilakukan dihadapan PPAT dibuktikan dengan adanya AJB yang merupakan salah satu akta otentik. Melalui akta otentik ditentukan kewajiban dan hak para pihak, menjamin kepastian hukum, dan sekaligus diharapkan pula dapat menghindari terjadinya sengketa. Dengan demikian, PPAT telah melaksanakan kewajiban sesuai dengan perannya. PPAT sangat berperan dalam memberikan kepastian dan memberikan perlindungan hukum bagi pihak yang berkepentingan.

\section{DAFTAR PUSTAKA}

Al-Rosyid, Harun, Sekilas tentang Jual Beli Tanab (Jakarta: Ghalia Indonesia, 1987).

Harsono, Boedi, Hukum Agraria Indonesia: Sejarah Pembentukan UndangUndang Pokok Agraria, Isi dan Pelaksanaannya (Jakarta: Djambatan, 1999).

Hartanto, J Andy, Hukum Pertanahan, Karakteristik Jual Beli Tanah yang Belum Terdaftar Hak Atas Tanahnya (Surabaya: LaksBang Justitia, 2014).

Parlindungan, AP, Komentar Atas Undang-Undang Pokok Agraria (Bandung: Madar Maju, 1991).

Perangin, Effendi, Hukum Agraria Indonesia: Suatu Telaab dari Sudut Pandang Praktisi Hukum (Jakarta: Radjawali, 1989).

Prajitno, AA Andi, Pengetahuan Praktis Tentang Apa dan Siapa PPAT (Malang: Selaras, 2013).

Santoso, Urip, Pendaftaran dan Peraliban Hak atas Tanah (Jakarta: Prenada Media Group, 2009).

Soekanto, Soerjono \& Sri Mamudji, Penelitian Normatif Suatu Tinjauan Singkat (Jakarta: PT Raja Grafindo Persada, 2013).

Soerodjo, Irawan, Kepastian Hukum Hak Atas Tanah di Indonesia (Surabaya: Arloks, 2003).

Sutedi, Adrian, Peraliban Hak atas Tanah dan Pendaftarannya (Jakarta: Sinar Grafika, 2014).

Akadol, Jamiat, Tamrin Muchsin \& Sri Sudono Saliro, "Kegagalan Mediasi: Sengketa Pertanahan di Kementerian Agraria Tata Ruang/Badan 
Pertanahan Nasional Sambas" (2020) 4:2 J Wawasan Yuridika 175.

Amborowati, Yulia, "Kekuatan Hukum Perjanjian Terhadap Perjanjian Pengikatan Jual Beli Hak atas Tanah dan Bangunan Yang Belum Terdaftar" (2020) 18:1 Al Qodiri J Pendidikan, Sos Dan Keagamaan 302-319.

Anggraeni, Shirley Zerlinda \& Marwanto Marwanto, "Kewenangan dan Tanggung Jawab Hukum Pejabat Pembuat Akta Tanah dalam Pelaksanaan Pendaftaran Hak Tanggungan Secara Elektronik" (2020) 5:2 Acta Com 261.

Disantara, Fradhana Putra, "Konsep Pluralisme Hukum Khas Indonesia sebagai Strategi Menghadapi Era Modernisasi Hukum” (2021) 6:1 AlAdalah J Huk dan Polit Islam 1-36.

Hamonangan, Norman \& Yusman Yusman, "Perbuatan Melawan Hukum Akibat Peralihan Hak Milik Tanah Ditinjau dari Pasal 1365 KUH Perdata dan Pasal 26 Undang-undang Nomor 5 Tahun 1960 Tentang Peraturan Dasar Pokok-pokok Agraria dan PP No. 24 tahun 1997

Tentang Pendaftaran Tanah (Studi Kasus Putusan" (2020) 3:1 Rechtsregel J Ilmu Huk 77.

Herera Yosifany Hutagalung, Daniella, "Perlindungan Hukum Terhadap Notaris dan PPAT sebagai Pihak Pelapor dalam Tindak Pidana Pencucian Uang" (2020) 34:1 Jatiswara.

Iryadi, Irfan, "Kedudukan Akta Otentik dalam Hubungannya dengan Hak Konstitusional Warga Negara" (2019) 15:4 J Konstitusi 796.

Iryadi, Irfan, "Kepastian Hukum Kedudukan Camat sebagai PPAT Sementara” (2020) 11:1 Negara Huk Membangun Huk untuk Keadilan dan Kesejaht 1-19.

Kristiani, Verlia, "Hukum yang Berkeadilan Bagi Hak Ulayat Masyarakat Hukum Adat (Kajian dan Implementasi)" (2020) 11:1 ADIL J Huk 143-163.

Kusuma, I Made Krishna Dharma, Putu Gede Seputra \& Luh Putu Suryani, "Peralihan Hak atas Tanah melalui Jual Beli Berdasarkan Hukum Adat" (2020) 1:2 J Interpret Huk 213-217.

Larasati, Ayu \& Raffles Raffles, "Peralihan Hak Atas Tanah dengan Perjanjian Jual Beli Menurut Hukum Pertanahan Indonesia” (2020) 1:1 Zaaken J Civ Bus Law 127-144. 
Made Emy Andayani Citra \& I Made Sudirga, "Eksistensi Program Pendaftaran Tanah Sistematis Lengkap (Ptsl) dalam Mencegah Terbitnya Sertipikat Ganda Di Kantor Pertanahan Kota Denpasar" (2020) 2:1 J Huk Sar 1-15.

Mardansyah, "Analisis Prosedur Administrasi Peralihan Hak atas Tanah Hibah pada Kementerian Agraria dan Tata Ruang/ Badan Pertanahan Nasional Kabupaten Bungo Provinsi Jambi” (2020) 5:1 Dialekt Publik J Adm Negara Univ Puter Batam 50- 59.

Monika, Della, "Analisis Yuridis Eksistensi Pejabat Pembuat Akta Tanah (PPAT) dalam Perspektif Pendaftaran Tanah di Kecamatan Tanjungpinang Timur (Studi Penelitian Dikantor Notaris dan Pejabat Pembuat Akta Tanah Afika Hersany)" (2020) 7:1 J Selat 65-86.

Mukmin, Abdul \& Andri Pranata, "Peran Kantor Pertanahan Kota Samarinda dalam Penyelesaian Sengketa dan Konflik Pertanahan" (2020) 12:2 Yuriska J Ilm Huk 148-159.

Murni, Christiana Sri, "Pendaftaran Peralihan Hak Milik atas Tanah Karena Pewarisan” (2020) 6:2 Lex Libr J Ilmu Huk 129-144.

Murni, Christiana Sri, "Peralihan Hak atas Tanah Tanpa Sertifikat" (2018) 4:2 Lex Libr J Ilmu Huk 680-692.

Muthallib, Abdul, "Pengaruh Sertifikat Hak atas Tanah sebagai Alat Bukti dalam Mencapai Kepastian Hukum” (2020) 12:1 Jurisprudensi J Ilmu Syariah, Perundang-undangan, dan Ekon Islam 21-43.

Natania, Dwina, Lastuti Abubakar \& Nanda A Lubis, "Penyampaian Akta Pemberian Hak Tanggungan oleh Pejabat Pembuat Akta Tanah setelah Diberlakukannya Peraturan Menteri ATR/KPBN Nomor 5 Tahun 2020 Tentang Pelayanan Hak Tanggungan Terintegrasi Secara Elektronik" (2020) 3:2 ACTA DIURNAL J Ilmu Huk Kenotaraiatan 273-291.

Nurbaedah, Nurbaedah, "Penyelesaian Sengketa Sumber Daya Agrari Pada Tanah Perkebunan Bekas Hak Guna Usaha" (2020) 6:2 Divers J Huk 220-233.

Saputra, Imam Surya, Ilyas Ismail \& Darmawan Darmawan, "Akibat Hukum Terhadap Akta Jual Beli yang Cacat Hukum” (2020) 8:2 J IUS Kaji Huk dan Keadilan 283.

Sisworini, Purwaning Rahayu, Abdul Majid \& Herman Suryokumoro, "Penerapan Honorarium PPAT sebagai Upaya untuk Penyetaraan 
Pelayanan (Studi Kasus Di Kota Malang)" (2020) 8:3 J IUS Kaji Huk dan Keadilan 512.

Surayya, Ita, "Idiologi Hukum Pendaftaran Tanah dalam Sistem Hukum Agraria" (2020) 34:1 Jatiswara.

Suwitra, I Made, "Eksistensi Tanah Adat dan Masalahnya Terhadap Penguatan Desa Adat Di Bali” (2020) 4:1 Wicaksana J Lingkung dan Pembang 31-44.

Wardhana, Mahendra et al, Registration of Electronic Integrated Mortgage Rights of the Written Certificate of Land Rights in the Name of the Debtor (Paris, France: Atlantis Press, 2020).

Wardhana, Mahendra, Indri Fogar Susilowati \& Dita Perwitasari, Registration of Transfers of Land of Rights for Nominee in the Post of Tax Amnesty (Paris, France: Atlantis Press, 2018). 